Article

\title{
Monocropping Cultures into Ruin: The Loss of Food Varieties and Cultural Diversity
}

\author{
Peter J. Jacques ${ }^{1, *}$ and Jessica Racine Jacques ${ }^{2}$ \\ 1 University of Central Florida, Department of Political Science, Orlando, Florida 32816, USA \\ 2 University of Central Florida, Department of Sociology, Orlando, Florida 32816, USA; \\ E-Mail: racinealtif@gmail.com \\ * Author to whom correspondence should be addressed; E-Mail: Peter.Jacques@ucf.edu; \\ Tel.: +1-407-823-6773; Fax: +1-407-823-0051.
}

Received: 21 July 2012; in revised form: 30 September 2012 / Accepted: 29 October 2012 / Published: 7 November 2012

\begin{abstract}
The loss of genetic diversity of thousands of plants and crops has been well documented at least since the 1970s, and has been understood as a result of epistemological and political economic conditions of the Green Revolution. The political economic arrangement of the Green Revolution, alongside a post-war focus on economies of scale and export-oriented growth, replace high-yield single varieties of crops for a diverse array of varieties that may not have the same yield, but may be able to resist pests, disease, and changing climatic conditions. Also, the harvest does not flow in all directions equally: Whereas small holder subsistence farming uses a large variety of crops as a food source and small-scale trade, the industrial economic system requires simplified, machine harvested ship-loads of one variety of maize, for example. Diverse varieties of different crops confound the machines, whereas one variety of wheat can be harvested with one setting on a machine. However, none of this is new. The purpose of this article is to analyze how the twin concerns of lost varietals and lost cultures are bound together in the socio-political process of standardization, and to explain some areas of resistance.
\end{abstract}

Keywords: Green Revolution; food security; food sovereignty; means of production; productive forces; culture; political ecology; political sociology 


\section{Introduction}

In the 1940s, Carl O. Sauer, a consultant to the instrumental Rockefeller Foundation, warned against the basic design of what would become industrialized agriculture, a.k.a., the Green Revolution:

A good aggressive bunch of American agronomists and plant breeders could ruin the native resources for good and all by pushing their American commercial stocks. The little agricultural work that has been done by experiment stations here [in Mexico] has been making that very mistake, by introducing U.S. forms instead of working on the selection of ecologically adjusted native items. The possibilities of disastrous destruction of local genes are great $(. .$.$) . Mexican agriculture cannot be pointed toward standardization on a few$ commercial types without upsetting native economy and culture hopelessly. (Letter from Sauer to Joseph Willits, director of the Rockefeller Foundation's Division of Social Science quoted in [1], p. 82, emphasis added).

Sauer's concern for both the social and ecological distress is remarkably prescient. Since the warnings of Sauer, the field of "biocultural" studies, which explores the "ultimate" link between biological diversity and cultural diversity, emerged in the 1990s; and, this field has discovered critical links between cultural and biological richness, indicating Sauer's suspicions were only the beginning [2]. The study of biocultural diversity has shown that the richest areas of language, ethnicities, and other cultural indicators, correlate and indeed coevolve with areas of both flora and fauna diversity $[3,4]$. There is a now an incontrovertible link between plants, animals, and lands that people gain material and non-material welfare from, and the knowledge systems, linguistic development, and cultural identity that grows with and within these ecological niches. Biological diversity refers to the overall number of individual species regardless of frequency, while evenness refers to "how similar the frequencies of the different variants are" ([5] p. 5326). Low evenness indicates variations are dominated by a single or few varieties and is a biological measure for homogenization of direct concern to our proposition. The threats to biological diversity are fairly well understood, if complex: loss of habitat, invasive forces that supplant endemic species subsistence, predation, and introduced diseases [6-9]. The forces that threaten biological diversity often threaten cultural diversity directly and indirectly, “(...) placing the world's diversity in both nature and culture increasingly at risk. This means no less than placing at risk the very basis of life on Earth as we know it: the natural life-supporting systems that have evolved on the planet, and their cultural counterparts have dynamically coevolved with them since the appearance of Homo sapiens" ([10], p. 56, see also [11,12]). Areas of rich biodiversity and cultural diversity show "parallel extinction risk" (indeed higher extinction risk than birds and mammals) [13], in part caused by "dramatic loss of livestock breeds and agricultural varieties as well as traditions for raising them, and erosion or obliteration of regional cuisines and foodways;" and, as diversity is being lost to homogeneity "almost everywhere" "forces promoting homogeneity are playing an endgame on a global scale" ([14], p. 317). Further, Jarvis, et al., have shown that there is a, "close linear relationship between traditional variety richness and evenness" where high evenness is supported by traditional 
farming communities [5]. Likewise, Lyson and Welsh, found that industrial agriculture in the U.S. suppresses biodiversity ([15], see also [16]).

Provided that decades of empirical work noted above conclusively demonstrate that industrial agriculture reduces bioculture, this article develops a political-sociology to explain how and why this relationship exists.

Cultural and biological diversity co-evolve in complex and constitutive feedbacks, and their losses are also complex. However, our argument is fairly simple: industrial agriculture selects only a few varieties for high yield, reducing evenness of both biological diversity and cultural variations through several long-standing patterns of bioculture. "Crops are the direct product of human selection on wild plant diversity" ([17], p. 450). In traditional farms, there is actually more diversity of staple varieties than non-staples, indicating traditional agriculture cultivates variation and difference at the farm and community levels [5]. If there are fewer cultures and knowledge to select a narrowing range of crops, diversity in crops falls alongside the loss of culture. Indeed, between the wild relatives and the industrial high-yield varieties, there has been a successive reduction of diversity. Initial selection of maize, for example, maintained only $57 \%$ of the wild DNA diversity [17]. Of these varieties, industrial agriculture has selected only five varieties of the initial "tens of thousands of open-pollinated cultivars of corn" ([17,18], p. 80). Food varieties come from diverse ecological systems, and these ecological systems are the environments within which knowledge is molded and encoded through language and culture as an adaptive response; therefore, homogenizing ecosystems through industrial agriculture selects adaptive features of language and culture, while this same process inhibits and obstructs the cultivation and freedom for the majority of biological organisms and cultures. Our purpose in this essay is to organize and propose a specific political sociology that explains these concomitant efforts of homogenization which clearly threaten social and ecological sustainability. Indeed, as cultures and biodiversity are lost to a more powerful and homogenizing set of forces, we do not need to wait for civilization collapse to occur, because these inter-dependent communities are not being sustained, and collapse, in this way, is already upon us.

In the process of shifting from local production for subsistence and nutrition to export-oriented, large scale agriculture, world food yield has increased and has kept up with the remarkable increase in world population during the 20th Century [19,20]. We do not contest this remarkable feat or deny that innovations in high-yield varieties and intensification of chemical and water inputs, mechanizations, and genetic sciences have produced much more yield per hectare of cropped land. Nor do we necessarily deny that the majority of chronically hungry people live in low-food producing countries that have not developed industrial agribusiness, while countries that have replaced chronic hunger with chronic obesity have strong agribusiness [19,21]. Southgate et al., believe critics of the Green Revolution ignore these points to feed populist suspicion of critical advances for civilization:

The critics of agribusiness pay little heed to the rural poverty that persists, in Sub-Saharan Africa and other places, where there are no specialized firms to provide inputs and marketing services to farmers. By the same token, they do not concede that farms in Europe, North America, and other prosperous settings are as prosperous as they are precisely because agribusiness is robust ([21], p. 47). 
We do contend, however, that these advances have come with remarkable costs. The processes of the Green Revolution have fostered critical contradictions while politically privileging some at the exacting price of others. Some of these costs have included shifts in allocation, distribution, and potential growth of food, the concentration of land to fewer owners, shifts in means of production and changes to class structures, global environmental changes to soil and water quality, biodiversity loss, and homogenization and loss of human culture. The latter two are the focus of this article. And, while the weaknesses of arguments against the Green Revolution indicate that a combination of industrial and traditional agriculture is necessary, the advocates of the Green Revolution often fail to acknowledge that industrialized agriculture is driven by a network of asymmetrical power and social values. Further, even if the prosperity of Europe and North America can be explained simply through robust agribusiness, the development of strong agribusiness in these two geopolitical centers depended on a subsidy of 11 million African slaves over 300 years in the slave-sugar-cotton triangle [22]. Slavery was the foundation for Atlantic industrial capitalism during the 16th-19th Centuries [23] and is a historical foundation of current Western dominance that is all too often forgotten. Of course, in order for there to be a viable area to create a slave-based plantation economy, there had to be land available and tenable, owing to colonial appropriation from indigenous peoples and a temperate climate in which to work. Thus, the argument that the Green Revolution should be exported because it has enriched North America and Europe and explains why hunger exists in the world's peripheral zones, conflates the notions of wealth and power while ignoring how these social conditions grew.

This essay extends Sauer's warning by explaining the process of standardization as striation and homogeneity with a predatory purpose and geography within a global political economic network of Industria, explained by Delueze and Guatarri and Hipwell respectively. First, we will connect culture as a reproductive force coevolving with biological diversity through the cultivation of crops. Then we will explain problems that come in the form of redistributing the "means to life" and self-sufficiency as a process of alienation familiar to Marx and Gramsci. These processes explain an increasing difficulty for different productive factors to survive. Now we will briefly explain how industrial agriculture has evolved since the post-War period into the 21 st Century.

\section{Industrial and Traditional Agriculture}

Industrial agriculture, commonly understood, intensifies inputs to maximize outputs. These inputs include fossil fuels and large amounts of energy, biocides, fertilizer, higher volumes of water, and farming machinery are all tools used for one goal: to maximize yield of large single variety crops at one time. Mushita and Thompson describe industrial agriculture as agriculture that changes plants to fit machines [24]. Harvesters, must be able to economically harvest a large amount of one kind of crop, thus varieties of crops in one field would make this impracticable, while the same ratios of the same chemicals, fertilizers, and water can be added at the same times making monoculture an attractive economic approach.

Certainly, neither industrial nor traditional agriculture are static monuments, but have adapted over time; and, it is likely that the future of food will require aspects of both systems [25]. The agroecological model is one such integrative adaptation that incorporates several important improvements to industrial monoculture. These adaptations include integrated pest management 
(natural pest management), agroforestry (working within forests instead of removing them), integrated nutrient management (cropping techniques to reduce chemical fertilizer use), conservation tillage (reducing the amount of soil disrupted for moisture management and erosion control), aquaculture (growing fish in or near shore), livestock integration (using livestock to enhance crops), and water harvesting (using degraded land for better water management). Further, as attempts toward more sustainable agriculture grow, "increased food production, as well as makes a positive impact on environmental goods and services" ([20], p. 459). All of these options restrain agricultural practices from over-exploiting the ecological cycles and systems that make agriculture possible, but "the total number of farmers using them worldwide is still relatively small" ([20], p. 455). Thus, mediating the costs of industrial agriculture remains more of a goal than an accomplishment. For example, rather than reducing nitrogen pollution from industrial agriculture nitrogen pollution has probably exceeded a critical sustainable boundary, continues to threaten human health, and has produced over 400 hypoxic or "dead zones" that can no longer support life. This problem contributes to "ecological extinction" where we are, in the ocean, "transforming complex food webs topped by big animals into simplified, microbially dominated ecosystems with boom and bust cycles of toxic dinoflagellate blooms, jellyfish, and disease" ([26], p. 11458, emphasis added, see also [27-29]).

That said, the central difference between industrial and traditional agricultural is epistemological. Industrial agriculture uses a formal scientific agronomic regime, "bolstered by intellectual property rights" ([30], p. 261) which serve what is essentially an economic project [31]. While the Global South was the test bed for the Green Revolution (Mexico, the Philippines, and India in particular), the agronomic scientific regime is explicitly Western because its Enlightenment epistemology of reductionist and separatist reasoning, where individual parts of bioculture, like genes, can be isolated, understood, and manipulated for instrumental gains outside of the larger biocultural context.

This agronomic epistemological regime is antithetical to traditional agriculture which "tends to mimic natural ecosystems" because they are adapted over time to local conditions and attempt to maintain functional elements of the landscape ([25], p. 331). Traditional agriculture is both a holistic cultural and ecological practice, with the purpose of human subsistence with dense meaning and tradition-foods are chosen for their meaning in religious ceremony, for example [31]. Traditional agriculture does not serve one master, so to speak, but many. Via advances in biotechnology, industrial agriculture attempts to control output for the purpose of economic growth, and it is "economistic" because economic values are more important than other competing values. Traditional agriculture is pluralistic — where economic values do exist, but they exist alongside cultural and ecological values. For example, Oguamanam writes of traditional agriculture:

It is a site for negotiating complex ecological relationships, whereof the sanctity of life forms, the holism of the natural order, and the compelling imperative for humanity's humble mediation and appreciation of its dependence on other life forces is more of a lived reality than a theoretical postulate ([30], p. 261).

From a political economic perspective, there are obvious differences in terms of capital, accumulation, and the rules of trade. Industrial agriculture is capital intensive, in that it requires a large amount of physical (e.g., machines) and financial (research and development) capital to maximize yield. This comes at the expense of natural capital, such as ecosystem services of soil 
formation, and human and social capital that holds the memory of how to plant varieties of endemic plants. Meanwhile, traditional agriculture intensifies human and social capital through collective experience mediating local, ecological spaces for subsistence through more common pool resources. Since industrial agriculture is mainly an economic project, the crops are a substitute for money, and it does not matter what crops are at stake, but rather growth in the accumulation of money. Traditional agriculture is used for trade and cash income, but also in ceremonies, subsistence, building social ties, and other socio-ecological elements, and what crops are planted and used make or break local nutrition, custom, and social structure.

It is worth noting that, in this paper, we will refer to traditional, indigenous and peasant agriculture interchangeably. While we may rightly identify differences between these systems, grouping them together makes sense because the epistemological and political economic approaches to agriculture are similar. In fact, peasants often are indigenous peoples, as in the Chipko movement [32]; and, some indigenous movements like the Zapatista resistance explicitly integrate peasant and indigenous populations into the same project and critique racialized boundaries that facilitate subjugation from powerful economic and state organs [33-35]. Of note, both of these movements concerned the self-determination, continuity, and sustainability of indigenous and peasant peoples and their traditional subsistence as they were threatened by industrial political economic forces.

\section{Feeding Culture}

Food production and consumption is a fundamental act of social reproduction. Food is produced in a dense array of social contexts that include economic values, historical and traditional meals, and the local knowledge needed to foster a crop in varied geographies. Wavqvist and Meei-Shyuan [36] describe food cultures as:

Food culture arises out of the place of a people's origin, whether they still live there or not, but is shaped by resources (climate, land, soil, water, and fuel), by belief and information (religion, education and literacy, communication), by ethnicity (indigenous or immigrant), technology (hunting, gathering, agricultural, horticultural, aquacultural, fishing; food processing and storage, transport, cooking); colonisation; and by health status and health care (p. 2).

Within these food cultures, "By and large, there is a remarkable resilience and ingenuity of people and their food systems, but monoculture and lack of diversity encourage food system failure" ([36], p. 2, emphasis added). Food systems and food cultures are embedded in political ecology.

Some of the more important questions in global food security and agrarian change have to do with taking "political ecology" seriously with particular attention to the complex array of productive forces in agriculture [37]. Martinez-Alier's defined political ecology as "the study of ecological distribution conflicts generated by modern (capitalist) economic growth," ([37], p. 301) which is "less and less sustainable" ([38], p. 256). Thus, one of the lesser explored conditions for agricultural change and sustainability is the political ecology of productive forces. In classical agricultural political economy, productive forces have remained under-theorized and, "tended to be restricted to the descriptive or 
contextual protocol, as it were, of studies of agrarian class structure and rural social change, with few exceptions" ([37], p. 300). In this article, we will argue that the dominant world capitalist system has worked to maximize productive forces that produce food at volume for profit at the expense of other systems that maximize resilience, traditional meaning, nutrition, taste and other values. This trade-off results in both cultural and biological homogenization, where the "distribution conflicts" noted by Martinez-Alier include the redistribution of the means of production found first in the Earth (below). Now, we will identify what we mean by culture.

Dimaggio [39] summarizes the concept of culture as a set of, "values that suffuse other aspects of belief, intention, and collective life has succumbed to one of culture as complex rule-like structures that constitute resources that can be put to strategic use" (p. 265). Other advances have come from biological anthropology and psychology that have shown culture emerges as a combination of biological and ecological adaptations, cognitive perception, representation, and political institutions [39-42]. For both Bourdieu [43] and Veblen [44], culture is a reflection of capital. Different classes have access to different forms of capital that generate different habits of material existence, which then form the cultural rules and even voluntary preferences of that group. Under these circumstances, cultural conditions reproduce class conditions and capitalist power [45]. We argue that as capital, such as land, seeds, and tools, changes to industrial modes, culture is standardized along with the crops; and, once begun, industrial culture reproduces itself, even through voluntary choices as farmers move more and more toward industrial modes of production away from traditional modes in hopes of higher profit. The farmers may, in fact, find this an advance in their living standards at times, but our theory is presented as an explanation for why bioculture is declining. Furthermore, certainly, farmers are not always better off, where many find themselves paying much higher costs for fertilizer, needing more pesticides, coming in contact with more poisons, under the oppression of mounting debt [46] - even if temporarily. Studies by Marten indicate that problems like the cyclic dependence on pesticides, is very real but can be reversed [46], and perhaps if the languages and practices of traditional cultures are not lost, they too, can be strengthened even after industrial agriculture had taken root.

For Bourdieu, "In the process of socialization, people in different class positions are exposed to different 'material conditions of existence,' which give rise to characteristic ways of perceiving and being in the world" ([45], p. 424).

Individuals with little capital are continually exposed to material scarcities and the consequent economic necessity of making a living, while those with greater capital share an objective distance from the material urgencies of life. The distance from economic necessity conditions different class habitus, which in turn generate different cultural tastes ([45], ibid).

Crucially, culture positions groups on a spectrum of distance from necessity. Classes with a large amount of capital can distance themselves substantially from "mundane material functions" [45] such as the labor and production of food and can focus on the "taste of freedom," aesthetic, and "conspicuous consumption" [44,45]. In this way, the kind and amount of capital provide direct material conditions for either a "down-to-earth," as Bourdieu puts it, ontological condition that depends on day to day cultivation and stewardship of land and local, diverse, food production (in the 
case of peasants), or an ontological condition that is farther removed where there is little or no daily concern for the productivity of the land or for the health of varietals. Like today's consumers who can simply switch to another fish when one is depleted, these varietals are abstract equivalents that take on much less social meaning to a consumer, and there is less opportunity for non-material spiritual, ethical, or emotional meaning. Classes with proximity to the dynamics of subsistence and the supporting ecological services, such as water cycles, animals of their region, the ways plants grow through a season, and the way soils change, have more opportunity to develop non-material meaning for these processes. Renown American Indian thinker, Vine Deloria [47], noted that it was the necessary adaptions indigenous tribes of North America made to live in a specific place, inter-dependent with non-human persons (such as the Bison Nation) and ecological cycles and systems, that generated intense cultural meaning, identity, and life-ways (ontology). These experiences also developed an awareness of the fragility of human prospect within indigenous cultures. As cultures have adapted to diverse places, diverse meaning, values, words, ideas and strategies, their cultures co-evolve with their environment as they also shape places, plants, animals, and cycles. Paramount to the Green Revolution, is the idea that a narrow kind of strain - and therefore a narrow approach to cultivation - can and should replace the "less-productive" (read: lower yield) strains and practices. Therefore, the coevolved and constitutive forces of rich biological organisms and rich varieties of cultures are supplanted with a narrow, if not singular, ideologically forceful ontology that has been changing the way people relate to the Earth and each other around the world.

The Green Revolution replaces the subsistence value of food for its surplus value (below), replacing a peasant class with a wage-labor class position. Also, in a world capitalist system, class divisions are not simply domestic, but operate as a network across national boundaries $[48,49]$ and the concept of world systems can be used to analyze patterns in world history going back to the origin of agriculture [50-53]. A world system is one with a unified market with a division of labor [49]. The division of labor is made up of core, semi-peripheral, and peripheral areas that serve as bourgeoisie, petit-bourgeoisie, and subsistence class groups with different kinds and amounts of capital that place each group in relative distance or proximity to the daily production of food. The hegemonic center becomes the model of the future [54], as the center attempts to remake the world in its image, and the culture of each class reproduces this structure, even voluntarily (though there is resistance, as we will discuss below). As a hegemonic force, voluntarism is important because the need for more rice, maize, and wheat in economies of scale is normalized and fails to even be questioned. This is the kind of hegemony Gramsci envisioned when he discussed the way power filtered through society, bending behavior without using a sword or gun, but through normalizing expectations that fit the goals of elite consumers and decision makers who do not feel the impacts of their consumption or related decisions [55]. Hegemony in the world system works in multiple ways, but we can focus on the example of hegemonic market relations and dependency to explain that hegemonic power is structural and constituted by systemic social relations, and does not require malicious people who want to do bad things. The Ainu of current-day Japan are instructive, explained by Brett Walker [56]. The productive systems of the Ainu were embedded in the forests and wetlands of Hokkaido, built on hunting, fishing, and plant-gathering for subsistence of several disparate chiefdoms that each had their own approach and different methods. However, trade with the shoganate of Matsumae brought grains and fabrics that the Ainu became dependent on, bringing the Ainu chiefdoms all into a similar productive system, 
because, in order to pay for these goods, the Ainu commodified their productive systems and began to see the deer and bear as things to trade, not kamuy - local gods that took the form of animals. The Ainu subsequently over-hunted and over-fished their land. The productive systems of the Ainu changed in its richness as it was over-exploited, and in its meaning as the gods were commodified into pelts for trade, particularly in rice. After some time, the gods become less plentiful, but dependence on rice grows. The market relation fundamentally shifts the culture, even in this case where the political power and prestige for Ainu huntsman incentivized voluntary commitment and cultural change. Now parts of this larger bioculture are regrettably altered or lost for good. This system of dependency is documented as well through changes in the productive systems and then culture of Choctaw, Pawnee and Dine' (Navajo) in of North America as well [57]. In these examples, there are combinations of structure and agency, empire and voluntarism, that combine the choices of the subaltern, but these choices are made within a the scaffolding of a growing world system that becomes taken for granted, obscuring alternatives, and this is a key feature of the hegemony found in the Green Revolution.

The examples above highlight a problem with world systems theory, which tends to oversimplify local/domestic divisions of labor and culture, and the fact that there are heterogeneous geographies within the larger organized system. A poor country will have geographies of privilege, such as the helicopter pads used for daily commuting in Rio de Janeiro; and, affluent countries have geographies of death, such as the Pine Ridge Sioux Reservation in South Dakota, U.S.A. where the mortality rate is the highest in the Western Hemisphere, except for Haiti [58]. We will address this problem below under the notion of Hipwell's [59] Industria, however, the point here is that there are heterogeneous geographies and divisions of labor locally - they are asymmetrical, while there is a larger world system that organizes the larger transnational rules and patterns of trade, production, and consumption. Of particular interest to the study of cultural diversity, are the pockets of abandonment and autonomy that exist largely outside the larger global economy because it is there that we find smallholder farmers who, worldwide, plant 1000s of varieties of crops in small spaces, mostly for their own subsistence and small-scale trade.

Within the global economy, the industrial food system economizes for scale, channels food for transportation and distribution away from the productive classes, and standardizes cultivars for ease and predictability of market profit and growth. For societies with fewer divisions of labor, less technological dependence, individuals form less stratified classes and use mostly similar forms of capital, and there is less economic hierarchy even amongst social rank and roles [47,60-62]. In this case, culture reproduces the material existence of relative equity (see [60]). Subsistence farming and food production are not based on efficiencies or economies of scale, but are optimized for other values that favor local social reproduction; meanwhile, culture dialectically reproduces the conditions for this subsistence based on the ontological conditions of available and historical natural capital.

In particular, large social forces found in a state/corporate alliance of power are organizing food and therefore food cultures within a world capitalist system standardizing food production in place of traditional food cultures that keep the value of the food systems mostly local. Traditional indigenous food cultures are those that reach back to the dawn of human civilization and even our speciation, and over long periods, ecological systems grew around human settlements such that "regional food diversity is a product of the natural environment and human settlement, with associated changes in wildlife, insects and micro-organisms too"- - but these origins of food are disappearing and "this may 
be a significant loss and threat to future personal health and security at the regional and international level" ([36], p. 5).

Take for example, the rice cultures of the Philippenes. Harrison [63] recounts the sacred role of rice in the highlands, the multitudes of languages that exist directly as a counterpart to the material relations of rice. In one village, one woman, trained since childhood, has the role of walking ahead of the harvest to collect seeds. Her knowledge is specific, based on perhaps hundreds or thousands of years of trial and error of growing rice in this space. Her knowledge is vital to feeding the village the following year. She speaks Ifugao, a language with an "intricate vocabulary of rice technology," that puts rice, a gift from extra-terrestrial "Skyward people," at the center of Ifugao culture ([63], p. 163). The Ifugao are surrounded by many similar cultures who speak different languages. Powerful interests connected to Green Revolution technologies, like the Philippine Rice Institute, "openly belittles traditional knowledge as useless folk-beliefs (...)" while the Institute advances high-yield varieties, industrial fertilizer, and chemical pesticide approaches through propaganda and short-term thinking about how much can be squeezed from the land [63]. These approaches bring short-term profit for the farmer, and they are appealing to many. As farmers adopt these approaches, they become dependent on technocratic knowledge and capital, and the technocrats do not speak Ifugao. Tagalog, the Philippine national language, as well as high yield hybrids that need pesticides and chemical fertilizer, are replacing the varieties of languages, peasant technologies, and traditional varieties of rice used for eons. This example demonstrates the direct relationship between lost crop diversity and cultural diversity. "Farmers in the Philippines now find themselves under pressure to abandon traditional rice technologies and even strains of rice bred over millennia by their ancestors," even as the international seed industry acknowledges that these traditional strains are, "selected, nurtured, improved by Third World farmers for hundreds, even thousands years" ([63], p. 164). The process toward short-term yields of single varieties is made possible by the varieties, knowledge, and values that the process eventually eliminates. When Ifugao is no longer spoken, the intricate knowledge about rice in Ifugao will be lost to the world while more people will speak English and Tagalog and rest their hopes on a more homogenous thin rail of high-yield varieties, untested for climate change, changes to diseases, or pests within volatile global economic conditions. The rice culture of Ifugao is reproduced by planting and cultivating its traditional strains of rice using the knowledge and technologies that have grown around this practice, and replacing new seeds and practices recodes the culture. The predatory network of Industria operates in a world capitalist system through real geographies of ports, rail lines, labs and farms, reaching into the diverse biocultures to recode and channel value to the core nodes for core consumption.

Indeed, cultures are diminishing like the seeds of so many plants. Linguists, for example, indicate that $60-90 \%$ of the world's 6800 languages will be extinguished by the end of century [11,64-66]. There are many forces that eliminate language and culture, not just a change in seeds or agricultural practices, but such changes are part of a larger repertoire. Several conditions appear to be putting pressure on different languages, but one central force is commerce, where trade draws the interest of knowing a language simply as a transaction. But, anthropologist and ethnobotonist, Wade Davis, argues that the central explanation for the loss of culture is power: "It is not change or technology that threatens culture; it is domination. The ultimate tragedy is not that archaic societies are disappearing but rather that avertible forces are driving vibrant peoples and languages out of 
existence" ([64], online). Standardizing one plant for one narrow purpose-trade-over all other means and ends that have fed thousands of cultures across time, is certainly a form of domination. This domination is mapped out through the idea of "striation."

\section{Standardization and Striation}

Since the 1920s and the work of Nikolai Ivanovich Vavilov [67], we have known that the staple crops that provide a majority of all human calories originated in 7-10 geographic hot spots with the most genetic diversity [68]. These hot spots are almost exclusively in the Global South.

Figure 1. Origins of Agriculture. Vavilov's original map of the origins of agriculture (1) Mexico-Guatemala, (2) Peru-Ecuador-Bolivia, (2A) Southern Chile, (2B) Southern Brazil, (3) Mediterranean, (4) Middle East, (5) Ethiopia, (6) Central Asia, (7) Indo-Burma, (7A) Siam-Malaya-Java, (8) China. (Image from Wikimedia Commons).

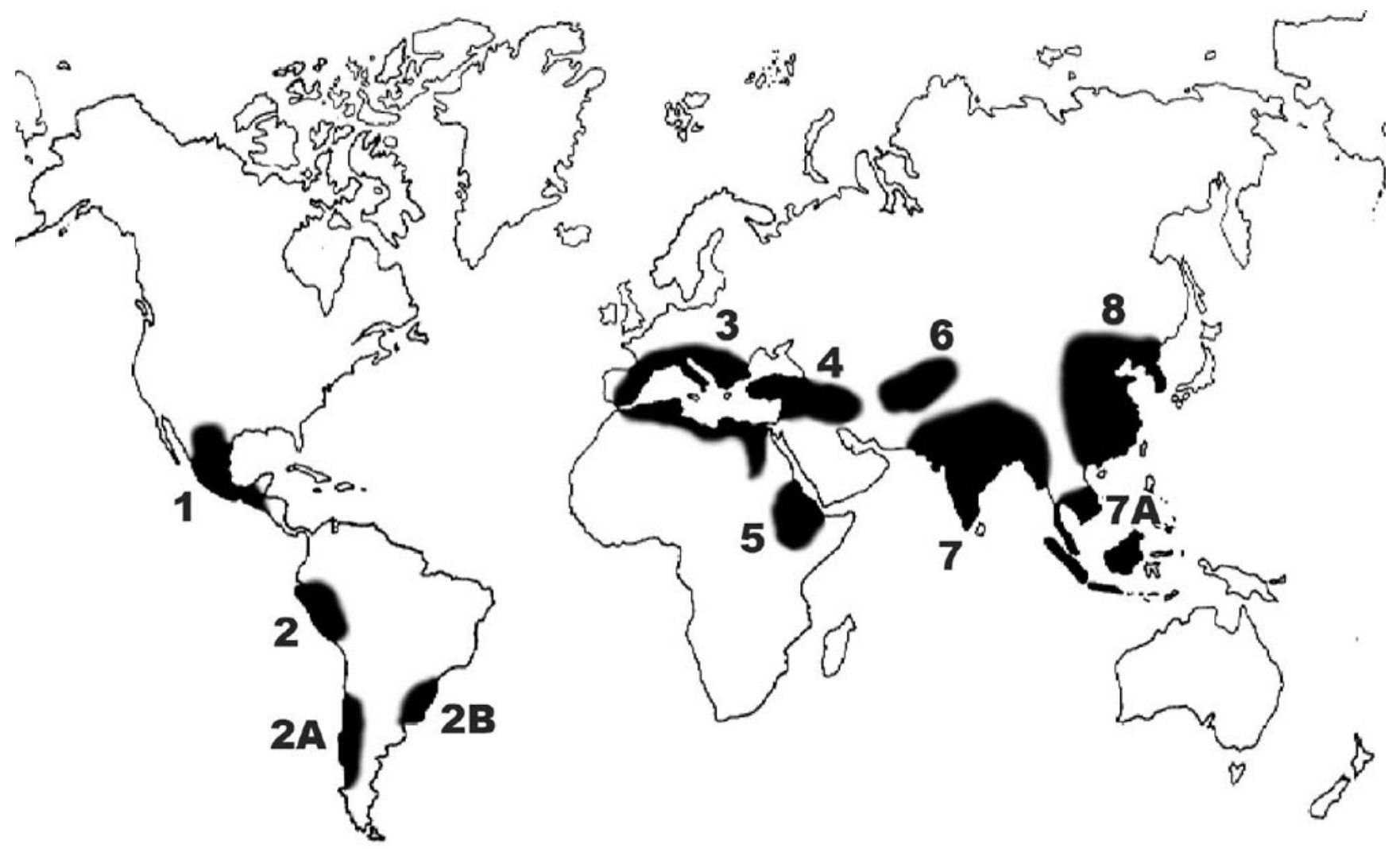

In 1973, Judith Miller warned in Science, that even at that beginning stage of the Green Revolution, "urbanization, economic development, and major advances in crop production have hastened the disappearance of thousands of genetically varied strains of plants and crops, products of thousands of years of evolution" ([69], p. 1231). She goes onto describe the now well-understood logic:

In the 1960's, the so-called Green Revolution began to spread through vast reaches of agricultural land in Latin America, Asia, and the Mediterranean nations, bringing harvests of new 'miracle' wheat and rice strains that promised to forestall global food shortages. In countries where the new, high-yield grains have become established, they have rapidly supplanted the native varieties (...). Thus, the array of strains on which future plant 
breeding depends has been dangerously narrowed, resulting in what plant geneticists call 'genetic erosion.' Moreover, mass planting of a single strain of rice or wheat creates genetic uniformity, which, in turn, makes the crop more susceptible to an epidemic ([69], Ibid, emphasis added).

The italicized text above indicates a contradiction of the Green Revolution, because in the process of standardizing genetic resources, it attacks the base and structure of its own reproductive power. The regions Miller notes conform remarkably to the origins of agriculture (Figure 1). From the very beginning, the Green Revolution depended on plant genetic resources for food and agriculture (PGRFA), such as the use of "wild Oryza longistaminata of the Xa21 gene for bacterial blight resistance" which became widely used in new rice hybrids ([70], p. 560). Meanwhile the Green Revolution has systematically eroded this very genetic diversity.

One of the first threats to PGRFA to be described occurred at the same time as, and because of, the Green Revolution in the 1960s and 1970s. Agricultural scientists and plant modern cultivars became successful and were taken up by farmers on a large scale, these modern varieties would rapidly replace the genetically rich traditional landraces that had existed for centuries. This has quite clearly happened between then and now and would have resulted in serious loss of the genetic diversity of traditional varieties had not genetic resources conservation in gene banks been implemented ([70], p. 561).

Indeed, since Vavilov, we have monocropped $75 \%$ of the genetic base of our subsistence into ruin - the vast majority is now gone [71] as a result of standardization [23]. Another way to think of standardization is through replacing diverse means and ends with a singular means to a singular end. William Hipwell $[59,72]$ takes the thinking of Deleuze and Guattari to make sense of the current world system. Hipwell explains the notion of striation, as, "Deleuze and Guattari's term for the mental or physical imposition of fixed, sedentary boundaries (enclosures) onto hitherto smooth space to create (...) 'homogeneous space of quantitative multiplicity' ([59], p. 360).

Such a reductive world view artificially substitutes difference, holism and continuity, where things in the world are stand-alone objects, instead of "intensities" that connect interdependently with a larger whole. For example, seeds are no longer part of a larger set of ecosystem processes built on millennia of evolution and human cultivation, but objects that can be separated and manipulated away from this whole. In separating the seed from the whole, the foundations of the seed are destroyed. Striated spaces are those that artificial order is imposed over "smooth spaces" of multiplicity and heterogeneity-difference. Further, this difference is not a simple set of different parts, but smooth spaces have a holistic, systemic integrity. Smooth spaces are always moving and are dynamic, and consequently they are difficult to control. Striation captures, standardizes, and channels diverse energy and matter for its own consumption, but this takes organizational and ideological power. This power can feed its own needs for production and reproduction by channeling that energy and material to its center-its core; and, this is necessary for imperialism because the imperial power has already simplified and homogenized much of the diverse energies and matter in its own space, for example in the erasure of wilderness, large predators, in-tact large ecosystems such as grasslands and old-growth forests (see $[73,74]$ ). When this power organizes a network around the world to feed the core nodes by harvesting the diverse, and therefore energy rich, hinterlands, we have the network of "Industria" so 
clearly articulated by Hipwell. Hipwell defines Industria as "a globalizing system of power/knowledge that has come to control most of the infrastructure of civilization" ([59], p. 48) Industria is a predatory global network that seeks out under-developed value. To do this, Industria categorizes a universalized reality into atomistic identities that can then be gathered and controlled by a state/corporate alliance. But, why is there value to be exploited in the areas outside the core?

Georgescu-Roegen [75] explains the kinds of values found outside of the core power centers. Georgescu-Roegen explained that entropy increased through the production cycle, because this cycle systemically removes useable complex energy for specific narrow purposes. For example, as a forest, there is nearly immeasurable energy in the complex array of matter, genes, habitat, nutrient cycling, support and participation in the hydrologic cycle, and photosynthesis, just to name a few. As a forest becomes lumber, and the lumber becomes a toothpick or desk, the usable energy is simplified and disorganized. Core power nodes have exploited their home complexity but continue to need more energy if they are to grow-an ideological commitment of profound importance. The core must then seek out new energy, and it finds it in peripheral areas that have not reduced or over-simplified their ecology. They then create relationships and extractive processes to capture this complexity, and channel it to the core for their own metabolic purposes; and, thus the core eats the periphery literally and metaphorically. Bunker [76] explains this as the process where the Northern core under-develops the Southern periphery by first exporting Northern institutions like the nation-state, class relations and privilege to identified locals, as well as infrastructure to transport raw materials. The core imports the forests, fisheries, and even people (slaves) for its own consumption. In this way, the North reproduces unequal ecological exchange, where it trades forests for desks and debt. The Southern periphery loses the energy sent away to the North and the necessary building blocks for its own development. Similarly, James C. Scott [77,78] argues that one of the great powers of the modern state apparatus has been be to apply laser-sharp focus on complex areas, like forests, in order to simplify, calculate, measure, and then control these diverse areas. The state only sees a regiment of trees for economic use, simplifying something complex for a "unique purpose and to be at the disposition of a single commander" ([78], p. 15). Simplification permits easier accounting, gathering, and channeling for this single use and narrow elite; and, but to find something to simplify, there needs to be areas not already denuded, which makes penetrating the peripheral woods, the field, and the sea so valuable. Redford and Brosius observe, "Rather than encouraging local diversity, the globalization of culture, foodways, languages, export crops, and exotic invasive species ensures that these local elements are replaced by exotic imports with wide distributions" enough that some have begun to call this historical period the "homogocene" ([14,23], p. 317).

Consequently, the search for complex values that have yet been standardized has a geography. Hipwell identifies this geography in his theory of Industria.

Industria is a web made up of lines of power: electrical transmission lines, pipelines, railways, telecommunications, paved roads, networks of experts and expertise. These lines constantly reach into new territory, snake-like, probing, investigating, naming, cataloguing, and mapping. Today, there are no longer any frontiers. The peripheries do not exist outside in the sense of traditional geometry. Industria is a web of geographical power completely 
encircling the Earth. Its periphery is found in the shrinking, wild spaces between the strands of the web. Above all else, Industria penetrates by knowing ([72], p. 308).

Industria uses "state-thought" - that totalizing instrumental logic of, "administrative, disciplinary, and technical strategies (...)" ([72], p. 307), and has now grown into a planetary system of control used to capture, channel and concentrate power into a state/corporate alliance, aligned by the ideology of growth [77-81]. Industria has a core network of nodes found in cities of the Global North, but which have a subsidiary set of nodes of cities in the Global South, that have harbors and railroads to channel timber, minerals, oil, and fish that are gathered by feller-bunchers, combines, and trawlers that send their quarry to the Global North. Least powerful in this network are the smooth, decentralized, and complex areas of the Global South hinterlands, perhaps because this area has not used its resources to concentrate power and organize in the fashion of city-zones. This is the world of indigenous peoples, of peasants, of many disparate cultures, and it is the world of the crop wild relatives. However, in order to increase volume and yield, the Green Revolution has had to narrow, focus and simplify the varieties of food by separating the ecological and cultural conditions of its production. Fundamentally, the means of production are a means to life in subsistence cultures, and re-coding these literally vital relationships for cash-related relationships is a form of alienation and it serves those classes who are more distant from the land.

\section{Alienation and a Means to a Life}

In The Economic and Philosophic Manuscripts, Marx writes:

Nature is man's inorganic body - nature, that is, insofar as it is not itself human body. Man lives on nature - means that nature is his body, with which he must remain in continuous interchange if he is not to die. That man's physical and spiritual life is linked to nature means simply that nature is linked to itself, for man is a part of nature" ([82], in "Estranged Labor" online).

While the life of peasants and indigenous peoples consists of daily labor and sometimes deprivation, the essential difference between a traditional culture and a modern culture is that traditional cultures that maintain their integrity, are not fundamentally alienated from ecological cycles and systems and the larger web of life, and therefore are not alienated from their physical and spiritual life. Life is tenuous for traditional cultures, but this life is connected to Earth systems and cycles, the larger food chain and the functions of biodiversity; and, the peasant's life is his/her own because the peasant and indigenous person is not defined as a commodity. In modern political economic systems, and therefore modern cultures, the peasant becomes a worker, and is removed from intimacy with the soil, their labor, their traditional cultures, languages, values, technologies, and life-ways to varying and asymmetrical ways at the same time they are made themselves into a commodity just like the fruit of their labor. In traditional political economies, and therefore traditional cultures, the fruit of traditional cultures is one that happens in a larger socio-ecological whole that must be balanced, and this balance, respect, restraint, and reciprocity is the focus of many traditional culture oral traditions (see [83,84]). In traditional cultures, violating the rules of the balance and restraint will often bring holistic ruin and 
even social collapse because the violation is one that fails to recognize the moral standing of non-human persons and nations, as well as the land and a larger sentient Earth [47,85-88].

However, when modern private property, aggregated in large agricultural projects and farms, inevitably organized by a state/corporate alliance, removes people from ancestral land, or even invites traditional cultures to try their high-input, high yield varieties of crops to replace traditional varieties and practices, the crops must pay bills (even when the farmer owns their own land), and the role of food then is that of commodity. This relation is essentially different than traditional cultures that can rely on their knowledge and adaptive institutions to live on their own, where no-one owns them or the means to life they have cultivated over the eons. We can see from the Eco-Tipping Points Project [46], that in places like Andra Predesh, India, where peasant farmers who simply tried Green Revolution technologies, became hooked into the system of debt, increasing pesticide needs, steep costs for production, higher debt, and even suicide. Thankfully, after some help from non-profit groups and on-the-ground non-corporate research, some of these farmers were able to escape this pesticide trap, and regain their means of production.

David Harvey writes that agriculture is a special case for value, where:

The land here not only supplies a stock of nutrients to be converted by plant growth and animal husbandry into food and sundry raw materials, bit also functions as an instrument or means of production. The production process is partially embodied within the soil itself ([89], p. 334, emphasis in original).

Use values are the "free gifts of nature" that people can live off of, but they are also the source of surplus value (excess profits) for capitalists who harvest these "free gifts," enclose them, and profit from them exclusively. The gifts have different qualities, and in places where use values have been preserved, there is more to harvest, creating rent [89]. Cultures that only have extracted use values have not extracted (much) rent from these "free" gifts, but have instead lived off of them and cultivated these areas. Use values therefore tend to reproduce cultures closer to the means of production of soil and the Earth.

The capitalist, however, does not live off of use value, but captures and encloses the richest gifts to create more profits. To do this, peasants and indigenous people who typically live in a mode of use values (mainly), must be alienated from these diverse subsistence means that will involve the use values of many flora and fauna at once. Capitalists must then enclose these free gifts for their own to capture the rent. The use values of seeds, for example, need to be enclosed and alienated from those who freely share them in the seed commons, in order to be profitable. Use values can remain local, do not need economies of scale to be of service, and the more diverse they are, the more uses they can serve and the more a family or village can hedge their bets against changes or failures in one aspect of their subsistence systems. Rent and surplus value, however, is more valuable in volume, and since the profit is in currency, any commodity that produces profit at economies of scale is equivalent. Standardization aids the latter process; but, the diversity of use values and free gifts (ecosystem goods and services) must be captured and alienated from peasants and indigenous or other local people, homogenized, and channeled for exchange.

There are several ways that traditional cultures are losing their means of production. Rosset [90] and others [91,92] have observed that African nations (at least Mali, Senegal, Sudan, 
The Democratic Republic of Congo and Uganda) are have succumbed to land-grabs from India, South Korea, Saudi Arabia and even South Africa who will use the land for rice cultivation - certainly not to address African malnutrition. This process of alienation of land is an age-old one reaching back to the colonial period, where imperial powers dismantled or undermined the subsistence base of indigenous peoples, with examples stretching from the extirpation of the bison (Plains Tribes of North America) to the elimination of amaranth (Inca) [24], deforestation in many areas like that of the Guarani (Paraguay, Bolivia, and Argentina) [93,94], and many others [47].

The case of the Guarani is instructive. The Guarani maintained a remarkable and sustainable agroforestry practice that used the forest in diverse ways to protect the base of their subsistence, the rainforest, while living a rich life with cultivated plants, hunted animals, and yerba mate for trade when desired. However, because the Guarani had protected their forest, it was not used up or simplified into stumps, and the forest became a target, and the Gaurani came under cultural attack. During the 1970s and 80s, Paraguay expanded its economy based on agricultural products: cotton, soy and wheat. Robbins notes that as incursions cut into Gaurani territory through roads, loggers and peasant settlers moved into the forest, enticed by government incentives. Fauna were hunted and faced severe habitat loss; flora, such as yerba mate, were eliminated and the "natural pharmacy" the Guarani used for treating illness was destroyed. "More to the point for this discussion, with the rainforests went the way of life of the Guarani”" ([93], p. 155). The means of production for Guarani culture had been razed. The Guarani were forced to assimilate into wage labor on the fields that replaced their forests, while they succumbed to disease without access to their traditional medicines, and their village and even family life were "recoded" and "reterritorialized" for industrial capitalist means of production [95] and cramped quarters in near-by urban centers. "By the 1980s, many people with "Ava" or "Simba" ancestors - some of their main terms of self-identification, together with ñandeva ("us")—-spoke only Spanish and did not identify as indigenous or did so ambiguously, largely because of the discrimination that the "Chaguancos," the denigrating term used regionally to refer to them, were regularly subjected to" ([95], p. 861). While "Guarani" is spoken in many places, the Guarani, as autonomous indigenous groups in charge of their own means of production, live on the edge of extinction [96]. In sum, the political ecology within which the Green Revolution took place in Guarani territories replaced agroforestry with agribusiness, removing one productive force for another, functionally eliminating culture along the way. Inasmuch as the means for life produce material conditions for culture, recoding the means of life recodes culture and material lives that people live together. The Guarani are among the many cultural groups that have been fragmented and assimilated through alienation from their traditional lands, use values, and means of life.

\section{Food Sovereignty and Lines of Flight}

Enormous pressures exist upon biodiversity and diverse cultures, each homogenizing and standardizing - neo-liberalism, economic globalization, and the Green Revolution. Indeed, Eric Hobsbawm [97] has argued that the modern conversions of agricultural production would bring the twilight and death of the peasant class, diminishing, if not eliminating, their class identity and any organizational power they may retain. However, organizing identities, drawing lines, and capturing 
energy not only feeds hegemonic power, it also spurs resistance. Indeed, Morton [98] as well as Moyo and Yeros [99] as well as believe that,

(...) despite ongoing problems of mobilization and political articulation, and under the most oppressive of circumstances, rural movements today constitute the core nucleus of opposition to neoliberalism and the most important sources of democratic transformation in national and international politics ([99], p. 6).

Capitalism creates a world system, but development is non-linear and asymmetrical, which means conditions are uneven and opportunities for land occupations, political demands, and other tactics have had, in some cases 500 years to develop. the peasant class is reconstituting, reorganizing, and resisting the overlapping threats of neo-liberalism, economic globalization, and the Green Revolution through historically reflexive counter-hegemonic activities [98].

"Lines of flight" are the "liberated flows that escape controlling relations of power" ([95], p. 872) contained by borders, these borders are constructed for the efficient capture by relations of power (such as a state/corporate alliance), and lines of flight for agrobiodiversity are working to reconstitute a holistic vision of resilient food systems that include biological and cultural diversity, language, religion, knowledge, and values. However, these resistance efforts go unnoticed by many because they are broadcast through subaltern channels compared to the meta-narrative of growth in the Green Revolution. Gramsci ([55] Vol. 2, p. 21) argued the history of subaltern classes is constantly fragmented unlike the history of the dominant voices of politics who can write a unified story populated with organic intellectuals who serve the interests of the elite. Instead, the subaltern classes' struggle in "anonymous toil" $[98,100]$ and their history is only partially told. Here, resistance is constantly attempting to tell a diverse set of stories, across a myriad of locales, often separated from a modern audience that can more easily hear about the wonders of genetically modified organisms and the higher yields for overall food supply. The message from Industria is told and recoded over a more unified set of channels and has a message that appeals to consumers who buy their food and do not grow it.

Many cultures continue to struggle against the state/corporate alliance of the Industrian network. One essential form of resistance, and one antidote to the problems of the Green Revolution, is to reclaim the means of production. In traditional societies, this means reclaiming the land, the sea, the streams, and other spaces. Indigenous resistance groups are reclaiming some land bases, like the Guarani have now done to a limited degree [94], and are working to protect their agricultural heritage, such as through native seed banks and exchanges, language programs for youth, and the practice of ceremonies. A great transnational peasant movement [101,102] has grown alongside a transnational indigenous movement $[103,104]$. The central demands of these movements is to protect their means of production - their land base, a rich genetic variety of flora and fauna for symbiotic subsistence (for biodiversity and cultural subsistence), and self-determination. The level of international participation is marked by a wide range of types of organizations, represented by the More and Better Network and its members in Appendix 1, one of which is Via Campesina which itself is made up of 148 organizations in 69 countries. These overlapping movements are large, transnational, and are working to disrupt the meta-narratives of growth and economies of scale that homogenize their ways of life, and therefore threaten their cultural existence. 
Importantly, traditional indigenous cultures are not vulgar Marxists, and they do not see the land and its inhabitants as simple capital, but as intimate relations. As George Tinker writes,

Some sense of what is at stake is apparent in a Lakota phrase that may be illustrative. Mitakouye oyasin can be translated as a prayer "for all my relations." As such it is inclusive not only of immediate family or even extended family, but of the whole tribe or nation; of all the nations of two-leggeds in the world; and particularly of all the nations other than two-leggeds - the four-leggeds, the wingeds, and the living-moving things. It is this interrelatedness that best captures what might symbolize for Indian peoples what Euro-Americans would call creation. More to the point, it is this understanding of interrelatedness, of balance and mutual respect among the different species of the world, that characterizes what we might call Indian people's greatest gift to Euro-Americans and to the Euro-American understanding of creation at this time of ecological crisis in the world ([88], p. 158).

This means that when cultures see their world as full of non-human persons, there is less motivation to simplify those communities into instrumental terms, such as surplus value and there is a consistent sense of interdependency with the rest of the web of life, as noted by Tinker. Meanwhile, Industria does not see a world full of non-human persons, and therefore there is no moral or ethical problem transforming the free gifts of nature into surplus value. Supplanting local, diverse bioculture for higher yield makes sense to this larger system of trade in economies of scale, but the cost is everything else that is included in diverse bioculture. As we have argued, protecting the means of production, however, is tantamount to protecting the culture.

These are all tenets of food sovereignty which focuses on self-sufficiency [24]. For example, Mies and Bennholdt-Thompson [105] write of the "subsistence perspective" to development that strives to protect diversity, self-reliance, and community support at the local level against the state/corporate alliance that attempts to enclose peasant commons and means to life.

\section{Conclusions}

Culture makes sense of and reproduces our material relationships, most critically — our subsistence relationships centered on food, while our material relations dialectically inform culture. For example, ecological conditions provided the opportunity to cultivate maize in current-day Mexico as one of the world's first crops; and, this ecological availability was a precursor to the maize culture and history tied to a national identity of Mexico, where growing maize is and has been a cornerstone for Mexican nation-building [31].

If the central mode of the Green Revolution is standardization, then dissimilarity, difference, and diversity are its antipodes - they are deviant. Homogenization of cultures is the same as assimilation and eradication, and diverse cultures themselves do not fit well into machines.

In traditional cultures, the means of production are the same as the means to life. As the Green Revolution replaces diverse agricultural strains with a narrow set of high-yield varieties, the capacity to reproduce these traditional cultures is undermined and choked out. This does not mean that we will see the twilight of the peasant, because there is a substantial movement to reclaim these means to life 
around the world, even in the Global North (see Appendix 1). Ironically, just as the Green Revolution undermines traditional cultures, it also generates a tremendous contradiction. The Green Revolution processes of intensive land use change, increased pollution, changes to the water cycle, and its participation in climate change all threaten the very productive base that permits the Green Revolution: the gene pool that includes plant wild relatives, and the cultures that know how to cultivate a wide array of varieties under dynamic conditions. To this extent, the contradictions of the Green Revolution not only threaten the security and sovereignty of peasants and indigenous peoples, but the security of the modern cultures that depend on this food, but who do not know how to grow it.

Protecting the means to life also means protecting biodiversity, and the cultural knowledge of a specific world that exists at a specific place; thus, as Deloria [47] so presciently explained, the struggle between space (locality) and time (universality) defines so much of our politics. Western cultures see the world through universal visions of time, where something is true universally across time if it is indeed true; meanwhile, indigenous cultures live in a space that contextualizes knowledge. Something is true in that space, but is not necessarily true everywhere; and, this knowledge is developed through trial and error, and memory. The former vision channels knowledge and then material life into striations that must fit universal categories for singular, economistic ends. Fewer varieties in the field and fewer cultures are both more efficient. The latter preserves the diversity of smooth spaces and complexity, on whole, because it lives together with this diversity and is dependent on the use values for resilience against pests, diseases, climate variations, and systemic surprises [106-109]. When the productive forces of diverse cultures are undermined by standardized industrial mechanics, long-term resilience, biodiversity, thousands of years of discrete cultural knowledge, and different values are traded for yield that creates surplus value, easily channeled to a powerful elite and subsidiary consumers in the world capitalist system. Industria is an efficient way to funnel power, knowledge and energy into short-term profits, but the very process has whittled away the genetic and cultural base that make the Green Revolution possible. This is a paradigmatic contradiction that should force the process of the Green Revolution to change, but —what will be left?

\section{Conflict of Interest}

The authors declare no conflict of interest.

\section{References}

1. McAFEE, K. Geographies of risk and difference in crop genetic engineering. Geogr. Rev. 2004, 94, 80-106.

2. Butler, S.J.; Brooks, D.; Feber, R.E.; Storkey, J.; Vickery, J.A.; Norris, K. A cross-taxonomic index for quantifying the health of farmland biodiversity. J. Appl. Ecol. 2009, 46, 1154-1162.

3. Green, R.E.; Cornell, S.J.; Scharlemann, J.P.W.; Balmford, A. Farming and the fate of wild nature. Science 2005, 307, 550-555.

4. Glover, J.D.; Reganold, J.P.; Cox, C.M. Agriculture: Plant perennials to save Africa's soils. Nature 2012, 489, 359-361. 
5. Jarvis, D.I.; Brown, A.H.D.; Cuong, P.H.; Collado-Panduro, L.; Latournerie-Moreno, L.; Gyawali, S.; Tanto, T.; Sawadogo, M.; Mar, I.; Sadiki, M.; et al. A global perspective of the richness and evenness of traditional crop-variety diversity maintained by farming communities. PNAS 2008, 105, 5326-5331.

6. Dirzo, R.; Raven, P.H. Global state of biodiversity and loss. Annu. Rev. Environ. Resour. 2003, 28, 137-167.

7. Chapin, F.S., III; Zavaleta, E.S.; Eviner, V.T.; Naylor, R.L.; Vitousek, P.M.; Reynolds, H.L.; Hooper, D.U.; Lavorel, S.; Sala, O.E.; Hobbie, S.E.; et al. Consequences of changing biodiversity. Nature 2000, 405, 234-242.

8. Myers, N.; Knoll, A.H. The biotic crisis and the future of evolution. PNAS 2001, 98, 5389-5392.

9. Pyšek, P.; Richardson, D.M. Invasive species, environmental change and management, and health. Annu. Rev. Environ. Resour. 2010, 35, 25-55.

10. Maffi, L. Bio-Cultural Diversity for Endogenous Development: Lessons from Research, Policy, and On-the-Ground Experiences. In Endogenous Development and Bio-Cultural Diversity: The Interplay of Worldviews Globalization and Locality, Geneva, Switzerland, 3-5 October 2006.

11. Maffi, L. Endangered languages, endangered knowledge. Int. Soc. Sci. J. 2002, 54, 385-393.

12. Harmon, D. Light of Our Differences: How Diversity in Nature and Culture Makes Us Human; Smithsonian Institute Scholarly Press: Washington, DC, USA, 2002.

13. Sutherland, W.J. Parallel extinction risk and global distribution of languages and species. Nature 2003, 423, 276-279.

14. Redford, K.H.; Brosius, J.P. Diversity and homogenization in the endgame. Global Environ. Change 2006, 16, 317-319.

15. Lyson, T.A.; Welsh, R. The production function, crop diversity, and the debate between conventional and sustainable agriculture. Rural Sociol. 1993, 58, 424-439.

16. Frankel, O.H. Genetic dangers in the green revolution. World Agr. 1970, 19, 9-13.

17. Vigouroux, Y.; Barnaud, A.; Scarcelli, N.; Thuillet, A.-C. Biodiversity, evolution and adaptation of cultivated crops. C. R. Biol. 2011, 334, 450-457.

18. Labate, J.A.; Lamkey, K.R.; Mitchell, S.E.; Kresovich, S.; Sullivan, H.; Smith, J.S.C. Molecular and historical aspects of corn belt dent diversity. Crop. Sci. 2003, 43, 80-91.

19. Paarlberg, R.L. Food Politics: What Everyone Needs to Know; Oxford University Press: Oxford, UK, 2010.

20. Pretty, J. Agricultural sustainability: Concepts, principles and evidence. Phil. Trans. Biol. Sci. 2008, 363, 447-465.

21. Southgate, D.; Graham, D.; Tweeten, L. The World Food Economy; Wiley-Blackwell: Malden, MA, USA, 2007.

22. Eltis, D. The volume and structure of the transatlantic slave trade: A reassessment. William Mary Q. 2001, 58, 17-46.

23. Bailey, R. The Slave(ry) trade and the development of capitalism in the United States: The textile industry in New England. Soc. Sci. Hist. 1990, 14, 373-414.

24. Mushita, A.; Thompson, C. Biopiracy of Biodiversity: Global Exchange as Enclosure; Africa World Press, Inc: Trenton, NJ, USA, 2007. 
25. Marten, G. Traditional Agriculture and Agricultural Research in Southeast Asia. In Traditional Agriculture in Southeast Asia a Human Ecology Perspective; Marten, G., Ed.; Westview Press: Boulder, CO, USA, 1986; pp. 326-340.

26. Jackson, J.B.C. Ecological extinction and evolution in the brave new ocean. PNAS 2008, 105, $11458-11465$.

27. Robertson, G.P.; Vitousek, P.M. Nitrogen in agriculture: Balancing the cost of an essential resource. Annu. Rev. Environ. Resour. 2009, 34, 97-125.

28. Rockstrom, J.; Steffen, W.; Noone, K.; Persson, A.; Chapin, F.S.; Lambin, E.F.; Lenton, T.M.; Scheffer, M.; Folke, C.; Schellnhuber, H.J.; et al. Planetary boundaries: Exploring the safe operating space for humanity. Ecol. Soc. 2009, 14, 32.

29. Diaz, R.J.; Rosenberg, R. Spreading dead zones and consequences for marine ecosystems. Science 2008, 321, 926-929.

30. Oguamanam, C. Tension on the farm fields: The death of traditional agriculture? Bull. Sci. Tech. Soc. 2007, 27, 260-273.

31. Cotter, J. Troubled Harvest: Agronomy and Revolution in Mexico, 1880-2002; Praeger: Westport, CT, USA, 2003.

32. Guha, R. The Unquiet Woods: Ecological Change and Peasant Resistance in the Himalaya; University of California Press: Ewing, NJ, USA, 2000.

33. Ridgeway, S.; Jacques, P. Population-conflict models: Blaming the poor for poverty. Soc. Sci. J. 2002, 39, 599-612.

34. Mora, M. Zapatista anticapitalist politics and the "other campaign": Learning from the struggle for indigenous rights and autonomy. Lat. Am. Perspect. 2007, 34, 64-77.

35. Vergara-Camus, L. The mst and the ezln struggle for land: New forms of peasant rebellions. J. Agrar. Change 2009, 9, 365-391.

36. Wahlqvist, M.L.; Meei-Shyuan, L. Regional food culture and development. Asia Pac. J. Clin. Nutr. 2007, 16, 2-7.

37. Bernstein, H. Introduction: Some questions concerning the productive forces. J. Agrar. Change 2010, 10, 300-314.

38. Martinez-Alier, J. The Environmentalism of the Poor: A Study of Ecological Conflicts and Valuation; Edward Elgar Publishing: Cheltenham, UK, 2002.

39. DiMaggio, P. Culture and cognition. Annu. Rev. Sociol. 1997, 23, 263-287.

40. Berezin, M. Politics and culture: A less fissured terrain. Annu. Rev. Sociol. 1997, 23, 361-383.

41. Kaufman, J. Endogenous explanation in the sociology of culture. Annu. Rev. Sociol. 2004, 30, $335-357$.

42. Durham, W.H. The adaptive significance of cultural behavior. Hum. Ecol. 1976, 4, 89-121.

43. Bourdieu, P. Distinction: A Social Critique of the Judgement of Taste; Harvard University Press: Cambridge, MA, USA, 1984.

44. Veblen, T. The Theory of the Leisure Class; Modern Library: New York, NY, USA, 1934.

45. Gartman, D. Culture as class symbolization or mass reification? A critique of Bourdieu's distinction. Am. J. Sociol. 1991, 97, 421-447. 
46. Marten, G. "Non-Pesticide Management" for Agricultural Pests: Escaping the Pesticide Trap-Controlling Pests without Chemical Pesticides Catapults Farmers from Chronic Poisoning and Debt to Health and Hope. Available online: http://www.ecotippingpoints.org/ourstories/indepth/india-pest-management-nonpesticide-neem.html (accessed on 14 July 2012).

47. Deloria, V. God Is Red: A Native View of Religion, 30th ed.; Fulcrum: Golden, CO, USA, 2003.

48. Wallerstein, I. The Modern World System; Academic Press: New York, NY, USA, 1989.

49. Wallerstein, I. World-Systems Analysis: An Introduction; Duke University Press: Durham, NC, USA, 2004.

50. Chase-Dunn, C.; Hall, T. Rise and Demise: Comparing World Systems; Westview Press: Boulder, CO, USA, 1997.

51. Hornberg, A.; Crumley, C. The World System and the Earth System: Global Socioenvironmental Change and Sustainability since the Neolithic; Left Coast Press: Walnut Creek, CA, USA, 2007.

52. Chew, S. World Ecological Degradation: Accumulation, Urbanization, and Deforestation; Altamira Press: Lanham, MD, USA, 2001.

53. Chew, S. The Recurring Dark Ages: Ecological Stress, Climate Changes, and System Transformation; AltaMira Press/Rowman and Littlefield: Lanham, MD, USA, 2007; Volume 2.

54. Chase-Dunn, C.; Taylor, P.; Arrighi, G.; Cox, R.; Overbeek, H.; Barry, G.; Frank, A.G.; Modelski, G.; Wilkinson, D. Hegemony and social change. Mershon Int. Stud. Rev. 1994, 38, 361-376.

55. Gramsci, A. Prison Notebooks; Columbia University Press: New York, NY; USA, 1996; Volumes 1-3.

56. Walker, B. The Ecology of Ainu Autonomy and Dependence. In The Indigenous Experience; Maaka, R., Andersen, C., Eds.; Canadian Scholars Press: Toronto, Canada, 2006; pp. 45-71.

57. White, R. Animals and Enterprise. In Milner, O'Connor and Sandweiss, The Oxford History of the American West; Oxford University Press: Oxford, UK, 1994.

58. Pickering, K. Culture and Reservation Economies. In A Companion to the Anthropology of American Indians; Blackwell Publishing: Oxford, UK, 2004; pp. 112-129.

59. Hipwell, W. A Deleuzian critique of resource-use management politics in Industria. The Canadian Geographer/Le Géographe Canadien 2004, 48, 356-377.

60. Poyer, L. Egalitarianism in the face of hierarchy. J. Anthropol. Res. 1993, 49, 111-133.

61. O'Brien, S. American Indian Tribal Governments; University of Oklahoma Press: Norman, OK, USA, 1989.

62. Howard, B.R. Indigenous Peoples and the State: The Struggle for Native Rights; Northern Illinois Press: Dekalb, IL, USA, 2003.

63. Harrison, K.D. When Languages Die: The Extinction of the World's Languages and the Erosion of Human Knowledge; Oxford University Press: New York, NY, USA, 2007.

64. Davis, W. Last of their kind. Sci. Am. 2010, 303, 60-67.

65. Le Quesne, W.J.F.; Pinnegar, J.K. The potential impacts of ocean acidification: Scaling from physiology to fisheries. Fish Fish. 2012, 13, 333-344.

66. Norgaard, R.B.; Baer, P. Collectively seeing complex systems: The nature of the problem. Bioscience 2005, 55, 953-960. 
67. Hertel, T.W. The global supply and demand for agricultural land in 2050: A perfect storm in the making? Am. J. Agric. Econ. 2011, 93, 259-275.

68. Jones, A.H.M. The Later Roman Empire, 284-602: A Social, Economic, and Administrative Survey; Johns Hopkins University Press: Baltimore, MD, USA, 1964.

69. Miller, J. Genetic erosion: Crop plants threatened by government neglect. Science 1973, 182, 1231-1233.

70. Ford-Lloyd, B.V.; Schmidt, M.; Armstrong, S.J.; Barazani, O.; Engels, J.; Hadas, R.; Hammer, K.; Kell, S.P.; Kang, D.; Khoshbakht, K.; et al. Crop wild relatives-undervalued, underutilized and under threat? Bioscience 2011, 61, 559-565.

71. Cordell, D.; Drangert, J.-O.; White, S. The story of phosphorus: Global food security and food for thought. Global Environ. Change 2009, 19, 292-305.

72. Hipwell, W.T. The industria hypothesis: 'The globalization of what?' Peace Rev. 2007, 19, 305-313.

73. Jacques, P.J. Globalization and the World Ocean; AltaMira/Rowman and Littlefield: Lanham, MD, USA, 2006.

74. Merchant, C. The Death of Nature: Women Ecology and the Scientific Revolution; Harper: New York, NY, USA, 1989.

75. Georgescu-Roegen, N. The Entropy Law and the Economic Process; Harvard University Press: Cambridge, MA, USA, 1971.

76. Bunker, S.G. Underdeveloping the Amazon: Extraction, Unequal Exchange, and the Failure of the Modern State; University of Chicago Press: Chicago, IL, USA, 1985.

77. Scott, J.C. State simplifications: Nature, space and people. J. Pol. Phil. 1995, 3, 191-233.

78. Scott, J.C. Seeing Like a State: How Certain Schemes to Improve the Human Condition Have Failed; Yale University Press: New Haven, CT, USA, 1998.

79. Hardt, M.; Negri, A. Empire; Harvard University Press: Cambridge, MA, USA, 2001.

80. Deleuze, G.; Guattari, F. A Thousand Plateaus: Capitalism and Schizophrenia; University of Minnesota Press: Minneapolis, MN, USA, 1987; Volume 2.

81. Saul, J.R. Voltaires Bastards: The Dictatorship of Reason; Penguin Books: Toronto, Canada, 2009; Volume 14.

82. Marx, K. The Economic and Philosophical Manuscripts; Vintage Books: New York, NY, USA, 1844.

83. Wall, D.; Masayesva, V. People of the corn: Teachings in hopi traditional agriculture, spirituality, and sustainability. Am. Indian. Q. 2004, 28, 435-454.

84. Jackson, M. Indigenous Law and the Sea; Island Press: Washington, DC, USA, 1993.

85. Waters, F. The Book of Hopi: The First Revelation of the Hopi's Historical and Religious World-View of Life; Penguin Books: New York, NY, USA, 1963.

86. Montejo, V. Mayan Ways of Knowing: Modern Mayans and the Elders. In The Will to Survive: Indigenous Essays on the Politics of Culture, Language, and Identity; Greymorning, S., Ed.; McGraw Hill: New York, NY, USA, 2004; pp. 154-170.

87. Wildcat, D. Red Alert! Saving the World with Indigenous Knowledge; Fulcrum: Golden, CO, USA, 2009. 
88. Tinker, G. An American Indian Theological Response to Eco-Justice. In Defending Mother Earth: Native American Perspectives on Environmental Justice; Weaver, J., Ed.; Orbis Books: Maryknoll, NY, USA, 1996.

89. Harvey, D.L. The Limits to Capital; Verso: New York, NY, USA, 2006.

90. Rosset, P. Food sovereignty and alternative paradigms to confront land grabbing and the food and climate crises. Development 2011, 54, 21-30.

91. Branford, S. The Great Global Land Grab. In Food and Democracy: Introduction to Food Sovereignity; Gerwin, C., Ed.; Polish Green Network: Krakow, Poland, 2011, p. 79.

92. The Grain Collective. Rice land grabs undermine food sovereignty in Africa. Development 2011, 54, 31-34.

93. Robbins, R. The Guarani: The Economics of Ethnocide. In The Indigenous Experience: Global Perspectives; Maaka, R., Andersen, C., Eds.; Canadian Scholar's Press: Toronto, Canada, 2006; pp. $150-157$.

94. Gordillo, G. Longing for elsewhere: Guaraní reterritorializations. Comp. Stud. Soc. Hist. 2011, $53,855-881$.

95. Norse, E.A.; Brooke, S.; Cheung, W.W.L.; Clark, M.R.; Ekeland, I.; Froese, R.; Gjerde, K.M.; Haedrich, R.L.; Heppell, S.S.; Morato, T.; et al. Sustainability of deep-sea fisheries. Mar. Policy 2012, 36, 307-320.

96. Millennium Ecosystem Assessment. Ecosystems and Human Well-Being: Our Human Planet: Summary for Decision-Makers; Island Press: Washington, DC, USA, 2005.

97. Hobsbawm, E. Age of Empire 1875-1914; Weidenfeld \& Nicolson: London, UK, 2010.

98. Morton, A.D. Global capitalism and the peasantry in Mexico: The recomposition of class struggle. J. Peasant Stud. 2007, 34, 441-473.

99. Moyo, S.; Yeros, P. Reclaiming the Land: The Resurgence of Rural Movements in Africa, Asia, and Latin America; Zed Books: London, UK, 2005.

100. Benjamin, W. Theses on the Philosophy of History. In The Holocaust: Theoretical Readings; Levi, N., Rothberg, M., Eds.; Rutgers University Press: New Brunswick, NJ, USA, 2003; pp. 277-279.

101. Hilmi, A. Agricultural Transition: A Different Logic; Naerstad, A., Ed.; The More and Better Network: Oslo, Norway, 2012.

102. Martínez-Torres, M.E.; Rosset, P.M. La vía campesina: The birth and evolution of a transnational social movement. J. Peasant Stud. 2010, 37, 149-175.

103. Hall, T.; Fenelon, J. The futures of indigenous peoples: 9-11 and the trajectory of indigenous survival and resistance. J. World Syst. Res. 2004, 10, 153-197.

104. Ridgeway, S.; Jacques, P. The Power of the Talking Stick: Indigenous Politics and the World Ecological Crisis; Paradigm Publishers: Boulder, CO, USA, 2013; forthcoming.

105. Mies, M.; Bennholdt-Thomsen, V. The Subsistence Perspective: Beyond the Globalised Economy; Zed Books Ltd.: New York, NY, USA, 1999.

106. Berkes, F.; Colding, J.; Folke, C. Navigating Social-Ecological Systems: Building Resilience for Complexity and Change; Cambridge University Press: Cambridge, UK, 2003. 
107. Berkes, F.; Folke, A.C. Back to the Future: Ecosystem Dynamics and Local Knowledge. In Panarchy: Understanding Transformations in Human and Natural Systems; Gunderson, L.H., Holling, C.S., Eds.; Island Press: Washington, DC, USA, 2002; pp. 121-146.

108. Berkes, F.; Folke, C. Linking Social and Ecological Systems: Management Practices and Social Mechanisms for Building Resilience; Cambridge University Press: Cambridge, UK, 1998.

109. Berkes, F.; Kislalioglu, M.; Folke, C.; Gadgil, M. Exploring the basic ecological unit: Ecosystem-like concepts in traditional societies. Ecosystems 1998, 1, 409-415.

\section{Appendix 1}

Members of the Transnational Peasant Movement organized through the More and Better Network [1].

\section{Africa:}

- Burkina Faso

- Initiatives d'e changes pour le dèveloppement durable-IEDD

Plate-forme DIOBASS Burkina Faso

- Cameroun

- Concertation Nationale des Organisations Paysannes de Cameroun-CNOP CAM

Conseil Rural pour le Développement de l'agricolture et la pêche-CORDAP

Federation of Young African Greens

PROPAC Plateforme sous-Régionale des Organisations Paysannes d'Afrique Centrale

- Congo Brazaville

- Concertacion Nationale des Organisations Paysannes-CNOP Congo

- Ethiopia

- Christian Relief and Development Association

- Civil Society Campaign Against Famine

- Ethio Organic Seeds Action-EOSA

Ogaden Welfare and Development Association-OWDA

Pastoralist Forum Ethiopia (PFE)

- Gabon

- Concertation Nationale des Organisations Paysannes du Gabon-CNOP Gabon

- Ghana

- Apex Farmers Organization of Ghana-APFOG

Development Action Association-DAA

Ecumenical Association for Sustainable Agriculture and Rural Development-ECASARD

- Kenya

- Kenya National Farmer's Union

Kenya National Federation of Agricultural Producers-KENFAP

Mubende Organic Forum

Ranje Sinoko Field Farmers School

- Malawi

- The Farmers Union

- CICANET

- Mali

- Concertation Nationale des Organisations Paysannes-CNOP Mali

- Mozambique

- União Nacional de Camponeses-UNAC

- Nigeria

- Center for Environmental Education and Development-CEED

- Federation of Nigeria Youth Greens-FNYG

- The United Small and Medium Scale Farmers' Association of Nigeria

- Trade Network Initiative-TNI

- RD Congo 
○ Cercle pour la Défense de l'Environment - CEDEN

- Senegal

- Cadre de Concertation des Producteurs d'Arachide-CCPA

- Coalition for the Protection of African Genetic Heritage - COPAGEN

- Fédération des ONG sénégalaises

○ Union des Comitès Ecologiques de la Vallée de Minky de Koungheul Socé-UCEM

- Tunisia

- APNEK Association for the Protection of Nature and Environment

- Association pour le Développement Durable-ADD

- Uganda

- Mubende Sustainable Organic Forum

- Support for Women in Agriculture and Environment-SWAGEN

- Uganda National Farmers Federation

- Zambia

○ Community Enterprises Promotion Network-CEPRON

\section{The Americas}

- Canada

- Canadian Foodgrains Bank USC Canada

- Chile

- Movimiento Agroecológico de América Latina y Caribe-MAELA

- Colombia

- FUNDAEXPRESIÓN-Fundación de Expresión Intercultural, Educativa y Ambiental

- Guatemala

- Fundación para la Innovación Tecnológica, Agropecuaria y Forestal—FUNDIT

- Honduras

- Participatory Plant Breeding in Meso-America

- Unión General Obrera Campesina y Popular A.C. Honduras

- Mexico

- Centro de Estudio para el Cambio del Campo Mexicano-CECCAM

○ Unión General Obrera Campesina y Popular A.C. Mexico

- Nicaragua

- Centro para la Investigación, Promoción y el Desarrollo Rural y Social—CIPRES

- USA

- Bread for the World

- Oakland Institute

\section{Asia}

- Bangladesh

- Bangladesh Krishok Federation

- India

○ Forum for Biotechnology \& Food Security

- Institute for motivating self-employment (IMSE)

- South Asian Network for Social \& Agricultural Development-SANSAD

- Indonesia

- Institute for Global Justice

- Iran

- The Centre for Sustainable Development (CENESTA)

- Jordan-Palestine

- Arab Group for the Protection of Nature

- Kazakhstan

- NGO Naurzum

- Kirdgikistan 
○ Kyrgys Sheep Breeders Association (KSBA)

- Malaysia

- Pesticide Action Network Asia-Pacific (PANAP)

- Nepal

- All Nepal Peasants Association (ANPA)

- Pakistan

○ Lok Sanjh Foundation

Pakistan Kissan Trust

Participatory Development Initiative (PDI)

- South Asia Partnership Pakistan (SAP-PAK)

- Phillipines

- Intergrated Rural Development Foundation (IRDF)

- Southeast Asia Regional Initiatives for Community Empowerment (SEARICE)

- Sri Lanka

- Sri Lanka Nature Forum (SLNF)

○ The Green Movement of Sri Lanka (GMSL)

\section{Europe}

- Belgium

- SOS FAIM

Finland

○ KEPA

- France

- Le Comité Français pour la Solidarité International

- Coordination SUD

- Germany

- Brot für die Welt

- Italy

- Action Aid International (Italy)

FOCSIV

Italian Campaign on Food Sovereignty

○ Terra Nuova

- Norway

- SPIRE

○ The Development Fund

- The Farmers Union

The Farmers' and Smallholders Union

○ The Norwegian More and Better campaign

- United Kingdom

○ UK Food Group

\section{International Organizations}

- Action Aid International

- African Biodiversity Network (ABN)

- African Youth Coalition against Hunger Namibia (AYCAH)

- Asia Pacific Network on Food Sovereignty

- Asian NGO Coalition for Agrarian Reforms and Rural Development (ANGOC)

- Bank Information Service (BIC)

- Forum of World Fisher Peoples (WFFP)

- International Federation of Organic Agriculture Movements (IFOAM)

- International Federation of Rural Adult Catholic Movements (FIMARC)

- Le Réseau des organisations paysannes et de producteurs de l'Afrique de l'Ouest (ROPPA)

- Movement of Catholic Agri-Rural Youth (MIJARC)

- Pesticide Action Network Asia-Pacific 
- URGENCI

- Via Campesina

- World Forum of World Fish Workers and Fisherpeoples

\section{Reference}

1. More and Better Organizations. Available online: http://www.moreandbetter.org/en/about/mborganizations (accessed on 5 October 2012).

(C) 2012 by the authors; licensee MDPI, Basel, Switzerland. This article is an open access article distributed under the terms and conditions of the Creative Commons Attribution license (http://creativecommons.org/licenses/by/3.0/). 